\title{
Hubungan Asap Rokok terhadap Derajat Keparahan Pneumonia Anak Usia di Bawah 5 Tahun
}

Maria Stefani, Andy Setiawan

Fakultas Kedokteran dan Ilmu Kesehatan Universitas Katolik Indonesia Atma Jaya, Jakarta

Latar belakang. Pneumonia merupakan penyebab utama kematian pada anak usia di bawah 5 tahun di dunia. Di Indonesia, prevalensi pneumonia pada anak di bawah usia 5 tahun mencapai 18,5 per mil. Paparan asap rokok merupakan salah satu faktor risiko pneumonia.

Tujuan. Membuktikan hubungan paparan asap rokok terhadap pneumonia berat pada anak usia di bawah 5 tahun. Metode. Penelitian ini merupakan studi kasus kontrol di Rumah Sakit Atma Jaya. Kelompok kasus didefinisikan sebagai anak usia di bawah 5 tahun dengan pneumonia berat, sedangkan kontrol merupakan anak dengan pneumonia sesuai klasifikasi WHO. Wawancara dilakukan terhadap orangtua responden untuk mendapatkan data paparan asap rokok. Analisis data menggunakan metode chi-square dan regresi logistik dengan tingkat signifikansi sebesar 0,05 .

Hasil. Penelitian ini melibatkan 67 responden, terdiri dari 34 kasus dan 33 kontrol. Analisis bivariat menunjukkan hubungan signifikan antara paparan asap rokok dengan pneumonia berat. Keberadaan perokok $(\mathrm{p}=0,000)$, jumlah perokok di rumah $(\mathrm{p}=0,000)$, perilaku orangtua merokok di dalam rumah $(\mathrm{p}=0,001)$ dan kepadatan rumah $(\mathrm{p}=0,012)$ merupakan faktor risiko yang signifikan terhadap kejadian pneumonia berat pada anak usia di bawah 5 tahun.

Kesimpulan. Paparan asap rokok dan kepadatan rumah merupakan faktor risiko pneumonia berat untuk anak usia di bawah 5 tahun. Sari Pediatri 2021;23(4):235-41

Kata kunci: pneumonia, paparan asap rokok, anak, derajat keparahan

\section{The Relationship of Tobacco Smoke Exposure on The Severity of Pneumonia Among Children Under The Age of 5}

Maria Stefani, Andy Setiawan

Background. Pneumonia is the leading cause of death in children under the age of 5 years globally. In Indonesia, the prevalence of pneumonia in children under five reaches 18.5 per mile. Tobacco smoke exposure is a risk factor for pneumonia.

Objective. To prove the relationship between tobacco smoke exposure and the severity of pneumonia among children under the age of 5 .

Methods. A case-control study was conducted at Atma Jaya Hospital. The cases included children with severe pneumonia, whereas the controls were children with pneumonia. Data of tobacco smoke exposure were obtained through interviews with parents. Data were analyzed using chi-square and logistic regression; significance level was set at 0.05 .

Result. We recruited 67 participants, consisting of 34 cases and 33 controls. Bivariate analyses showed a strong relationship between tobacco smoke exposure and severe pneumonia. The presence of smokers $(\mathrm{p}=0.000)$, number of smokers at home $(\mathrm{p}=0.000)$, parent's smoking behavior at home $(\mathrm{p}=0.001)$, and crowding $(\mathrm{p}=0.012)$ were significant risk factors of severe pneumonia among children under the age of 5 .

Conclusion. Tobacco smoke exposure and crowding were risk factors for severe pneumonia among children under the age of 5 . Sari Pediatri 2021;23(4):235-41

Keywords: pneumonia, tobacco smoke exposure, children, severity

Alamat korespondensi: Andy Setiawan. Fakultas Kedokteran dan Ilmu Kesehatan UNIKA Atma Jaya. Jl. Pluit Raya 2, Jakarta 14440. Email: andy.setiawan@atmajaya. ac.id 
Maria Stefani dkk: Hubungan asap rokok terhadap derajat keparahan pneumonia anak usia di bawah 5 tahun

$\mathrm{P}$ neumonia merupakan penyebab kematian utama akibat infeksi pada anak berusia di bawah 5 tahun di dunia. ${ }^{1}$ Penyakit ini menyebabkan sekitar $18 \%$ dari semua kematian pada anak di bawah 5 tahun dan 99\% di antaranya terjadi di negara berpenghasilan rendah dan menengah. ${ }^{2} \mathrm{Di}$ Indonesia, prevalensi pneumonia pada anak di bawah 5 tahun mencapai 18,5 permil. ${ }^{3}$ Pneumonia merupakan peradangan pada parenkim paru yang dapat disebabkan oleh virus, bakteri, protozoa, jamur, atau penyebab noninfeksi lainnya. ${ }^{4}$ Umumnya, pneumonia ditemukan pada individu dengan imunitas lemah, terutama anakanak. ${ }^{4,5}$ Derajat keparahan pneumonia ditentukan saat pertama kali datang ke rumah sakit. Hal ini penting agar anak dapat menerima pengobatan yang tepat.

Insiden pneumonia di negara berkembang dipengaruhi oleh banyak faktor risiko, seperti berat badan lahir, status gizi dan imunisasi, pemberian ASI, kepadatan rumah, lingkungan, pendidikan ibu, dan paparan asap rokok. ${ }^{2,6}$ Asap rokok merupakan salah satu ancaman terbesar terhadap kesehatan masyarakat, membunuh lebih dari 7 juta orang setiap tahunnya, 1,2 juta di antaranya merupakan akibat dari paparan asap rokok. ${ }^{7}$ Menurut data World Health Organization (WHO) tahun 2017, Indonesia menempati urutan ketiga jumlah perokok terbanyak di dunia. ${ }^{8}$ Asap rokok meningkatkan risiko penyakit infeksi karena memiliki efek supresi terhadap imunitas saluran pernapasan. Infeksi tersebut dapat bersifat mengancam jiwa dan berdampak pada semua perokok, baik perokok aktif maupun perokok pasif. ${ }^{9}$ Anak dengan orangtua yang merokok memiliki risiko lebih tinggi terpapar asap rokok karena mereka mempunyai kontak fisik yang lebih dekat dengan orangtuanya, serta dengan permukaan dan debu yang terkontaminasi oleh asap rokok. ${ }^{10}$

Penelitian ini bertujuan untuk membuktikan hubungan paparan asap rokok terhadap pneumonia berat pada anak usia di bawah 5 tahun. Tujuan khusus penelitian ini yaitu membuktikan hubungan keberadaaan perokok di rumah, jumlah perokok, jumlah rokok yang dikonsumsi orangtua, dan jumlah orangtua yang merokok terhadap pneumonia berat. Jika paparan asap rokok berdampak signifikan terhadap derajat keparahan pneumonia, maka tindakan yang diambil untuk mengurangi paparan asap rokok dari orangtua akan menurunkan beban penyakit pneumonia pada anak.

\section{Metode}

Studi kasus kontrol retrospektif ini dilaksanakan pada bulan Februari hingga Agustus 2019 di Rumah Sakit Atma Jaya. Sampel dalam penelitian ini adalah semua anak usia di bawah 5 tahun dengan diagnosis pneumonia dan dirawat di Bagian Ilmu Kesehatan Anak Rumah Sakit Atma Jaya pada bulan Januari hingga Desember 2017. Data sosio-demografi dan derajat pneumonia diperoleh dari rekam medis, sedangkan data paparan asap rokok diperoleh dengan wawancara orangtua lewat telepon. Penelitian ini telah mendapat persetujuan dari Komite Etik Penelitian Kesehatan Fakultas Kedokteran dan Ilmu Kesehatan Universitas Katolik Indonesia Atma Jaya, Jakarta.

Kriteria inklusi adalah pasien usia $0-59$ bulan dengan diagnosis pneumonia, usia gestasi $\geq 35$ minggu dan berat badan lahir $\geq 2500$ gram. Pasien dengan penyakit kongenital, status imunokompromais, meningitis, dan ensefalitis dieksklusi dari penelitian ini. Kelompok kasus didefinisikan sebagai anak dengan pneumonia berat, sedangkan kelompok kontrol merupakan anak dengan pneumonia. Klasifikasi derajat keparahan ini didasarkan pada klasifikasi WHO tahun 2014. ${ }^{11}$ Variabel yang diambil adalah usia, jenis kelamin, status gizi, status imunisasi, kepadatan rumah, status pendidikan ibu, dan paparan asap rokok.

Besar sampel penelitian ditentukan menggunakan rumus Fleiss. ${ }^{12}$ Dengan ditetapkan tingkat kepercayaan pada 95\% dan kekuatan sebesar 80\%; dibutuhkan 23 anak per kelompok. Oleh karena itu, pada penelitian ini dibutuhkan jumlah sampel minimal 46 anak. Analisis univariat dan bivariat digunakan dengan program SPSS versi 23. Analisis univariat bertujuan untuk mendeskripsikan karakteristik dan menggambarkan distribusi frekuensi masing-masing variabel. Analisis bivariat dengan chi-square digunakan untuk mengetahui hubungan antara variabel dependen dan variabel independen. Tingkat signifikansi dinyatakan pada interval kepercayaan $95 \%$ atau $\mathrm{p}<0,05$. Analisis multivaria dengan uji regresi logistik dilakukan untuk mengetahui variabel independen yang mempunyai pengaruh paling besar terhadap variabel dependen dan melihat apakah hubungan variabel independen dan dependen dipengaruhi oleh variabel lainnya.

Pneumonia berat didefinisikan sebagai anak dengan pneumonia yang memiliki tanda-tanda bahaya umum, yaitu tidak bisa minum, muntah persisten, kejang, 
letargi atau tidak sadar, stridor pada anak yang tenang, atau malnutrisi berat. ${ }^{11}$ Malnutrisi didefinisikan sebagai berat badan berdasarkan tinggi badan berada di bawah -3 SD pada grafik standar pertumbuhan anak WHO. ${ }^{13}$ Status imunisasi dikatakan lengkap apabila memenuhi imunisasi sesuai usia berdasarkan rekomendasi Ikatan Dokter Anak Indonesia (IDAI) ${ }^{14}$ Kepadatan rumah didefinisikan sebagai memiliki $>2$ orang yang tinggal dalam satu ruangan. ${ }^{15}$ Pendidikan ibu diklasifikasikan menjadi $\leq 9$ tahun atau $>9$ tahun berdasarkan program wajib belajar di Indonesia. ${ }^{16}$ Paparan asap rokok dinilai dari keberadaan perokok di rumah, jumlah perokok di rumah, jumlah batang rokok per hari yang dikonsumsi orangtua, dan perilaku orangtua merokok di dalam rumah. ${ }^{17}$ Berdasarkan jumlah batang rokok per hari yang dikonsumsi orangtua, responden dikelompokkan menjadi kelompok perokok berat (orangtua merokok $\geq 20$ batang/hari) dan perokok ringan (orangtua merokok $1-19$ batang/hari). ${ }^{18}$

\section{Hasil}

Responden pada pengambilan data rekam medis bulan Januari sampai Desember 2017 yang sesuai dengan kriteria eligibilitas yang sudah ditentukan sejumlah 67 orang, terdiri dari 34 kasus dan 33 kontrol. Baik kasus maupun kontrol lebih banyak ditemukan pada laki-laki $(55,2 \%)$ dan pada kelompok usia $0-23$ bulan $(70,1 \%)$. Karakteristik sosio-demografi sampel dari penelitian tertera pada pada Tabel 1 .

Hasil analisis bivariat dari data sosio-demografi tertera pada Tabel 2. Pada rumah yang padat, pneumonia berat lebih sering terjadi $(60,4 \%)$ dibandingkan pneumonia (39,6\%). Analisis chi-square antara kepadatan rumah dengan pneumonia berat menunjukkan hubungan bermakna dengan nilai $\mathrm{p}$ 0,012 (OR=4,274; IK95\%=1,322-13,819). Dalam penelitian ini, persentase pneumonia berat lebih tinggi pada kelompok yang tidak mengalami malnutrisi $(85,7 \%)$, memiliki status imunisasi tidak lengkap $(57,1 \%)$ dan pada kelompok pendidikan ibu $\leq 9$ tahun $(59,5 \%)$. Analisis data dengan chi-square menunjukkan bahwa usia $(\mathrm{p}=0,650)$, jenis kelamin $(\mathrm{p}=0,274)$ malnutrisi $(\mathrm{p}=0,673)$, status imunisasi $(\mathrm{p}=1,000)$, dan pendidikan ibu $(\mathrm{p}=0,113)$ tidak memiliki hubungan signifikan dengan pneumonia berat.

Tabel 3 menunjukkan hasil analisis bivariat dari variabel paparan asap rokok. Sebanyak 39 (58,2\%) responden mendapatkan paparan asap rokok. Pada kelompok yang mendapatkan paparan, terdapat 31 $(79,5 \%)$ responden dengan pneumonia berat. Analisis data menunjukan adanya hubungan antara keberadaan perokok dengan pneumonia berat $(\mathrm{p}=0,0001)$. Analisis lebih lanjut mengenai jumlah perokok di rumah pada kelompok responden yang terpapar menunjukkan hubungan signifikan $(\mathrm{p}=0,0001)$, baik untuk kategori 1 perokok $(\mathrm{OR}=26,190$; IK95\%=6,029-113,778) maupun $\geq 2$ perokok $(\mathrm{OR}=75,000$; IK $95 \%$ 6,886$816,858)$ di rumah. Sebanyak $30(76,9 \%)$ responden pada kelompok terpapar memiliki orangtua perokok di dalam rumah. Di antaranya, terdapat 28 (93,3\%) responden yang menderita pneumonia berat, sedangkan hanya terdapat $3(33,3 \%)$ dengan pneumonia berat pada kelompok orangtua yang tidak merokok di dalam rumah. Analisis data nilai p sebesar $0,001(\mathrm{OR}=28,000$; IK95\% =3,810-205,791), menunjukkan adanya hubungan bermakna antara perilaku orangtua merokok di rumah dengan pneumonia berat.

Tabel 1. Karakteristik sosio-demografi subjek penelitian

\begin{tabular}{lc}
\hline Karakteristik & $\mathrm{N}=67$ \\
\hline Usia (bulan) & $47(70,1)$ \\
$0-23$ & $20(29,9)$ \\
$24-59$ & \\
Jenis kelamin & $37(55,2)$ \\
$\quad$ Laki-laki & $30(44,8)$ \\
Perempuan & \\
Status gizi (BB/TB) & $6(8,9)$ \\
$<-3$ SD & $9(13,4)$ \\
-3 SD s/d -2 SD & $44(65,7)$ \\
-2 SD s/d 2 SD & $6(8,9)$ \\
2 SD s/d 3 SD & $2(3)$ \\
$>3$ SD & \\
Status imunisasi & $7(10,4)$ \\
Tidak lengkap & $60(89,6)$ \\
Lengkap & \\
Kepadatan rumah & $48(71,6)$ \\
Ya & $19(28,4)$ \\
Tidak & \\
Pendidikan ibu (tahun) & $37(55,2)$ \\
$\leq 9$ & $30(44,8)$ \\
$>9$ & $67(100)$ \\
\hline Total & \\
\hline &
\end{tabular}


Pada penelitian ini terdapat $26(66,7 \%)$ responden dalam kategori perokok berat dan 13 (33,3\%) responden dalam kategori perokok ringan. Hasil analisis data menunjukkan nilai $\mathrm{p}=0,402$, sehingga dapat ditarik kesimpulan bahwa tidak ada hubungan bermakna antara jumlah konsumsi rokok orangtua dengan derajat keparahan pneumonia. Variabel independen yang memiliki hubungan bermakna pada analisis bivariat, yaitu kepadatan rumah dan keberadaan perokok di rumah, dianalisis lagi dengan uji regresi logistik. Hasil analisis multivariat dengan uji regresi logistik tertera pada Tabel 4 dan menunjukkan bahwa pada analisis multivariat hanya keberadaan perokok di rumah yang memiliki hubungan bermakna dengan pnumonia berat $(\mathrm{p}<0,001 ; \mathrm{OR}=28,952, \mathrm{IK} 95 \%=6,447-130,020$.

\section{Pembahasan}

Hasil analisis bivariat menunjukkan bahwa faktor risiko untuk terjadinya pneumonia berat pada anak usia di bawah 5 tahun meliputi kepadatan rumah, keberadaan perokok di rumah, jumlah perokok di rumah dan kebiasaan orangtua merokok di dalam rumah. Variabel paparan asap rokok secara keseluruhan menunjukkan hubungan bermakna dengan derajat keparahan pneumonia. Hubungan ini tetap bermakna setelah dilakukan analisis multivariat dengan menggunakan faktor kepadatan rumah sebagai variabel pengganggu. Interval kepercayaan yang lebar pada beberapa analisis variabel paparan asap rokok dapat disebabkan karena sedikitnya jumlah kasus yang tidak menerima paparan asap rokok. Konsisten dengan temuan kami, sebuah penelitian yang dilakukan oleh Ahn $\mathrm{dkk}^{19}$ melaporkan hubungan antara keberadaan perokok dan risiko pneumonia berat pada anak. Dalam penelitian kami, baik 1 perokok dan 2 perokok memiliki hubungan bermakna dengan pneumonia berat dan menunjukkan perbandingan lurus antara jumlah perokok dengan risiko pneumonia berat. Temuan ini berbeda dengan hasil dari penelitian Ahn $\mathrm{dkk}^{19}$ yang menyatakan bahwa hanya anak dari rumah dengan 2 perokok yang memiliki masa rawat inap lebih lama dan cenderung membutuhkan perawatan intensif. Dalam penelitian ini tidak ditemukan hubungan yang bermakna antara jumlah batang rokok per hari yang dikonsumsi oleh orangtua dengan derajat keparahan pneumonia anak.

Tabel 2. Analisis bivariat dari variabel sosio-demografi

\begin{tabular}{|c|c|c|c|c|}
\hline Variabel & $\begin{array}{c}\text { Pneumonia berat } \\
\mathrm{n}=34(\%)\end{array}$ & $\begin{array}{l}\text { Pneumonia } \\
\mathrm{n}=33(\%)\end{array}$ & Nilai $\mathrm{p}^{*}$ & $\begin{array}{l}\text { Odds ratio } \\
\text { (IK 95\%) }\end{array}$ \\
\hline \multicolumn{5}{|l|}{ Usia, (bulan) } \\
\hline $0-23$ & $23(48,9)$ & $24(51,1)$ & 0,650 & 0,784 \\
\hline $24-59$ & $11(55,0)$ & $9(45,0)$ & & $(0,274-2,241)$ \\
\hline \multicolumn{5}{|l|}{ Jenis kelamin } \\
\hline Laki-laki & $21(56,8)$ & $16(43,2)$ & 0,274 & 1,176 \\
\hline Perempuan & $13(43,3)$ & $17(56,7)$ & & $(0,694-4,536)$ \\
\hline \multicolumn{5}{|l|}{ Malnutrisi } \\
\hline Ya & $4(66,7)$ & $2(33,3)$ & 0,673 & 2,067 \\
\hline Tidak & $30(49,2)$ & $31(50,8)$ & & $(0,352-12,134)$ \\
\hline \multicolumn{5}{|l|}{ Status imunisasi } \\
\hline Tidak lengkap & $4(57,1)$ & $3(42,9)$ & 1,000 & 1,333 \\
\hline Lengkap & $30(50,0)$ & $30(50,0)$ & & $(0,275-6,474)$ \\
\hline \multicolumn{5}{|l|}{ Kepadatan rumah } \\
\hline Ya & $29(60,4)$ & $19(39,6)$ & 0,012 & 4,274 \\
\hline Tidak & $5(26,3)$ & $14(73,7)$ & & $(1,322-13,819)$ \\
\hline \multicolumn{5}{|c|}{ Pendidikan ibu (tahun) } \\
\hline$\leq 9$ & $22(59,5)$ & $15(40,5)$ & 0,113 & 2,200 \\
\hline$>9$ & $12(40,0)$ & $18(60,0)$ & & $(0,824-5,873)$ \\
\hline
\end{tabular}

${ }^{*}$ Analisis menggunakan uji chi-square 
Maria Stefani dkk: Hubungan asap rokok terhadap derajat keparahan pneumonia anak usia di bawah 5 tahun

Tabel 3. Analisis bivariat dari variabel paparan asap rokok

\begin{tabular}{|c|c|c|c|c|}
\hline Paparan asap rokok & $\begin{array}{c}\text { Pneumonia } \\
\text { berat }(\%)\end{array}$ & Pneumonia (\%) & Nilai $\mathrm{p}^{*}$ & $\begin{array}{l}\text { Odds Ratio } \\
\text { (IK 95\%) }\end{array}$ \\
\hline \multicolumn{5}{|c|}{ Keberadaan perokok di rumah } \\
\hline Ya & $31(79,5)$ & $8(20,5)$ & 0,0001 & 32,292 \\
\hline Tidak & $3(10,7)$ & $25(89,3)$ & & $(7,746-134,623)$ \\
\hline \multicolumn{5}{|l|}{ Jumlah perokok di rumah } \\
\hline$\geq 2$ & $9(90,0)$ & $1(10,0)$ & 0,0001 & $\begin{array}{c}75,000 \\
(6,886-816,858)\end{array}$ \\
\hline 1 & $22(75,9)$ & $7(24,1)$ & 0,0001 & $\begin{array}{c}26,190 \\
(6,029-113,778)\end{array}$ \\
\hline 0 & $3(10,7)$ & $25(89,3)$ & & Referensi \\
\hline \multicolumn{5}{|c|}{$\begin{array}{l}\text { Jumlah rokok yang dikonsumsi orangtua } \\
\text { (batang/hari) }\end{array}$} \\
\hline Perokok berat $(\geq 20)$ & $22(84,6)$ & $4(15,4)$ & 0,402 & 2,444 \\
\hline Perokok ringan $(1-10)$ & $9(69,2)$ & $4(30,8)$ & & $(0,499-11,965)$ \\
\hline \multicolumn{5}{|c|}{ Orangtua merokok di dalam rumah } \\
\hline Ya & $28(93,3)$ & $2(6,7)$ & 0,001 & 28,000 \\
\hline Tidak & $3(33,3)$ & $6(66,7)$ & & $(3,810-205,791)$ \\
\hline
\end{tabular}

Tabel 4. Analisis multivariat dengan regresi logistik

\begin{tabular}{lcc}
\hline Variabel & Nilai p & $\begin{array}{c}\text { Odds Ratio } \\
\text { (IK 95\%) }\end{array}$ \\
\hline Kepadatan rumah & 0,687 & 1,395 \\
Keberadaan perokok di rumah & $<0,001$ & $(0,276-7,040)$ \\
& & 28,952 \\
\hline
\end{tabular}

Hubungan bermakna ditemukan antara perilaku merokok orangtua di rumah dengan risiko pneumonia berat. Perilaku merokok di dalam rumah mencerminkan paparan rokok yang berasal dari secondhand dan thirdhand smoke. Temuan ini serupa dengan hasil penelitian Matt $\mathrm{dkk}^{20}$ mengenai paparan asap rokok di rumah pada anak. Penelitian tersebut menunjukkan bahwa paparan asap rokok lebih tinggi $2-6$ kali lipat pada anak dengan orangtua yang merokok di dalam rumah dibandingkan dengan mereka yang orangtuanya merokok di luar rumah. ${ }^{20}$ Sebuah studi yang dilaksanakan oleh PrayGod $\mathrm{dkk}^{21}$ di Tanzania menunjukkan bahwa anak di bawah 2 tahun memiliki risiko pneumonia berat, sedangkan hasil serupa tidak ditemukan pada penelitian kami. Hal ini dapat dijelaskan oleh besarnya perbedaan proporsi antara kelompok usia $0-23$ bulan $(70,1 \%)$ dan $24-$ 59 bulan $(29,9 \%)$.

Beberapa faktor risiko yang sudah diketahui untuk pneumonia, seperti status imunisasi tidak lengkap dan malnutrisi, tidak ditemukan memiliki hubungan bermakna pada populasi dalam studi ini. Temuan ini serupa dengan temuan Jroundi $\mathrm{dkk}^{22}$ di Morocco dan Ngocho dkk ${ }^{23}$ di Tanzania. Kedua studi ini tidak menemukan hubungan bermakna antara imunisasi dan pneumonia berat. Beberapa faktor dapat berkontribusi pada temuan ini, seperti kenyataan bahwa hanya sebagian kecil anak yang belum menyelesaikan vaksinasi sesuai usia $(10,4 \%)$. Cakupan vaksin yang tinggi memungkinkan kekebalan kelompok (herd immunity) untuk anak yang tidak divaksinasi. ${ }^{24,25}$ Berbeda dengan hasil yang ditemukan oleh Hoang $\mathrm{dkk},{ }^{26}$ malnutrisi tidak memiliki hubungan bermakna dengan pneumonia berat dalam penelitian ini. Hubungan tersebut dapat disebabkan oleh perbedaan proporsi yang besar.

Selaras dengan temuan Gupta dkk, ${ }^{27}$ yang melaporkan hubungan antara kepadatan rumah dengan pneumonia berat. Tinggal di rumah yang padat mendorong penularan patogen airborne dan 
meningkatkan jumlah inokulum yang menginfeksi. ${ }^{15}$ Penelitian sebelumnya telah menunjukkan bahwa kepadatan rumah merupakan faktor risiko independen untuk pneumonia berat akut pada anak. ${ }^{15}$ Hubungan ini menjadi tidak bermakna setelah dilakukan analisis multivariat. Kisworini $\mathrm{dkk}^{28}$ tidak menemukan hubungan antara pendidikan ibu dan tingkat keparahan pneumonia. Pendidikan ibu memengaruhi kepatuhan terhadap regimen pengobatan, follow-up, praktik rujukan dan pengambilan keputusan untuk kesehatan anak, tetapi banyak faktor lain yang dapat memengaruhi proses pengambilan keputusan, seperti status sosial ekonomi, usia ibu, dan faktor sosial budaya. ${ }^{28,29}$

Studi kami merupakan salah satu studi pertama yang menyelidiki hubungan antara paparan asap rokok pada anak dengan derajat keparahan pneumonia menggunakan kriteria WHO 2014. Dalam penelitian kami, 79,5\% anak dengan pneumonia berat terpapar asap rokok di rumah. Namun, hal tersebut tidak teridentifikasi dalam rekam medis saat kunjungan ke rumah sakit. Kesadaran orangtua atau pengasuh mengenai lingkungan bebas asap rokok bagi anak sangat penting. Konseling dan edukasi perlu dilakukan dan rawat inap akut untuk penyakit pernapasan, terutama pneumonia, merupakan kesempatan yang tepat. ${ }^{30}$ Peningkatan alat skrining paparan asap rokok berpotensi untuk mengurangi beban penyakit pneumonia pada anak.

Keterbatasan studi kami meliputi desain retrospektif dan data paparan yang didapatkan dari wawancara lewat telepon sehingga dapat mengakibatkan recall bias. Data objektif paparan asap rokok, seperti kadar kotinin dalam urin, rambut, dan air liur, juga tidak dinilai dalam studi ini. ${ }^{31,32}$ Penelitian ini juga tidak menilai paparan yang didapatkan dari luar rumah walaupun paparan pada anak kebanyakan didapatkan dari rumah. Keterbatasan tersebut tidak mengurangi fakta bahwa paparan asap rokok membawa dampak yang buruk terhadap derajat keparahan pneumonia anak.

\section{Kesimpulan}

Penelitian ini membuktikan adanya hubungan antara kepadatan rumah dan paparan asap rokok terhadap pneumonia berat pada anak usia di bawah 5 tahun. Keberadaan perokok di rumah, jumlah perokok di rumah, dan perilaku orangtua merokok di dalam rumah merupakan faktor risiko signifikan yang meningkatkan insidensi pneumonia berat pada anak usia di bawah 5 tahun. Penelitian lebih lanjut dibutuhkan untuk meneliti hubungan antara kepadatan rumah dan pneumonia berat pada anak usia di bawah 5 tahun.

\section{Daftar pustaka}

1. Liu L, Oza S, Hogan D, dkk. Global, regional, and national causes of child mortality in $2000-13$, with projections to inform post-2015 priorities: an updated systematic analysis. Lancet 2015;385:430-40.

2. World Health Organization. Priority medicines for Europe and the world update report. Geneva: World Health Organization; 2013.

3. Badan Penelitian dan Pengembangan Kesehatan Kementerian Kesehatan RI. Riset Kesehatan Dasar. Indonesia: Badan Penelitian dan Pengembangan Kesehatan Kementerian Kesehatan RI; 2013.

4. Kasper DL, Fauci AS, Hauser SL, dkk. Harrison's principles of internal medicine. Edisi ke-19. New York: McGraw Hill; 2015. h. 803-9.

5. Kliegman R, Stanton B, St. Geme JW, Schor NF, Behrman RE. Nelson textbook of pediatrics. Edisi ke-20. Philadelphia, PA: Elsevier; 2016. h. 2088-93.

6. Ramezani M, Aemmi SZ, Moghadam ZE. Factors affecting the rate of pediatric pneumonia in developing countries: a review and literature study. Int J Pediatr 2015;3:1173-81.

7. World Health Organization. Tobacco: fact sheets. Geneva: World Health Organization; Jul 2019. Diunduh pada 20 Agustus 2019. Didapat dari: https://www.who.int/news-room/ fact-sheets/detail/tobacco.

8. World Health Organization. WHO report on the global tobacco epidemic: country profile Indonesia. Geneva: World Health Organization; 2017.

9. Feldman C, Anderson R. Cigarette smoking and mechanisms of susceptibility to infections of the respiratory tract and other organ systems. J Infect 2013;67:169-84.

10. Drehmer JE, Walters BH, Nabi-Burza, Winickoff JP. Guidance for the clinical management of thirdhand smoke exposure in child health-care setting. J Clin Outcomes Manag 2017;24:551-9.

11. World Health Organization. Revised WHO classification and treatment of pneumonia in children at health facilities. Geneva: World Health Organization; 2014.

12. Fleiss Jl, Levin F, Paik MC. Statistical Methods for Rates and Proportions. Edisi ke-3. New York: John Wiley \& Sons, Inc; 2003.

13. World Health Organization. WHO Child Growth Standards. Geneva: World Health Organization; 2006.

14. Ikatan Dokter Anak Indonesia. Jadwal Imunisasi IDAI 2017. Indonesia: Ikatan Dokter Anak Indonesia; Apr 2017. Diunduh pada 20 Jul 2018. Didapat dari: http://www.idai.or.idlartikel/ klinik/imunisasiljadwal-imunisasi-2017.

15. Fonseca Lima EJ, Mello MJ, Albuquerque MF, Lopes MI, 
Serra GH, Lima DE. Risk factors for community-acquired pneumonia in children under five years of age in the postpneumococcal conjugate vaccine era in Brazil: a case control study. BMC Pediatr 2016;16:157.

16. Pemerintah Indonesia. Undang-Undang No. 20 Tahun 2003 tentang Sistem Pendidikan Nasional. Lembaran Negara RI Tahun 2003 No. 78. Jakarta: Sekretariat Negara; 2003.

17. Couluris M, Schnapf BM, Casey A, Xu P, Gross-King M, Krischer J. How to measure secondhand smoke exposure in a pediatric clinic setting. Arch Pediatr Adolesc Med 2011;165:670-1

18. Neumann T, Rasmussen M, Heitmann BL, Tonnesen H. Gold standard program for heavy smokers in a real-life setting. Int J Environ Res Public Health 2013;10:4186-99.

19. Ahn A, Edwards KM, Grijalva CG, dkk. Secondhand smoke exposure and illness severity among children hospitalized with pneumonia. J Pediatr 2015;167:869-74.

20. Matt GE, Quintana PJ, Hovell MF, dkk. Households contaminated by environmental tobacco smoke: sources of infant exposures. Tob Control 2004;13:29-37.

21. PrayGod G, Mukerebe C, Magawa R, Jeremiah K, Torok ME. Indoor air pollution and delayed measles vaccination increase the risk of severe pneumonia in children: results from a case-control study in Mwanza, Tanzania. PLoS One 2016;11:e0160804.

22. Jroundi I, Mahraoui C, Benmessaoud R, dkk. Risk factors for a poor outcome among children admitted with clinically severe pneumonia to a university hospital in Rabat, Morocco. Int J Infect Dis 2014;28:164-70.

23. Ngocho JS, de Jonge MI, Minja L, dkk. Modifiable risk factors for community-acquired pneumonia in children under 5 years of age in resource-poor settings: a case-control study. Trop Med Int Health 2019;24:484-92.

24. Principi N, Esposito S. Prevention of community-acquired pneumonia with available pneumococcal vaccines. Int J Mol Sci 2017;18:30.

25. Dunne EM, Satzke C, Ratu FT, dkk. Effect of tenvalent pneumococcal conjugate vaccine introduction of pneumococcal carriage in Fiji: results from four annual crosssectional carriage surveys. Lacet Glob Health 2018;6:1375-85.

26. Hoang VT, Dao TL, Minodier P, dkk. Risk factors for severe pneumonia according to WHO 2005 criteria definition among children $<5$ years of age in Thai Binh, Vietnam: a case-control study. J Epidemiol Glob Health 2019;9:274-80.

27. Gupta N, Bhadrala N. Risk factors for acute severe pneumonia in under five children. Int J Contemp Pediatr 2019;6:949-54.

28. Kisworini P, Setyati A, Sutaryo. Mortality predictors of pneumonia in children. Paeditr Indones 2010;50:150-3.

29. Onwunaka C, Nwimo IO, Ilo CI, Okafor JO. Maternal compliance practices during childhood pneumonia in Imo State, Nigeria. J Health, Med Nurs 2015;15:72-7.

30. Mahabee-Gittens EM. Missed opportunities to intervene with caregivers of young children highly exposed to secondhand tobacco smoke. Prev Med 2014;69:304-5.

31. Kim S, Apelberg BJ, Avila-Tang E, dkk. Utility and cutoff value of hair nicotine as a biomarker of long-term tobacco smoke exposure, compared to salivary cotinine. Int J Environ Res Public Health 2014;11:8368-82.

32. Mahabee-Gittens EM, Merianos AL, Gordon JS, dkk. Electronic Health Record Classification of Tobacco Smoke Exposure and Cotinine Levels in Hospitalized Pediatric Patients. Hosp Pediatr 2019;9:659-64. 